\title{
Penerapan Metode Iqra' dalam Pembelajaran Membaca Alquran
}

\author{
Nur Hasnah ${ }^{1}$, Indah Muliati ${ }^{2}$ \\ nhasnah566@gmail.com ${ }^{1}$, indahmuliati1979@gmail.com² \\ Universitas Negeri Padang1,2
}

\begin{tabular}{|c|c|}
\hline ARTICLE INFO & \multirow{12}{*}{$\begin{array}{l}\text { ABSTRACT } \\
\text { This study aims to examine the application of the } \\
\text { iqra' method in learning to read the Qur'an. This study used } \\
\text { a qualitative method with a descriptive analysis approach, } \\
\text { research data were taken through direct interviews with } 7 \\
\text { informants. To strengthen the interview data, the writer } \\
\text { made observations by looking directly at the process of } \\
\text { learning to read the Qur'an using the Iqra' method. The data } \\
\text { obtained were then analyzed by data reduction, data } \\
\text { presentation, and drawing conclusions, after which a } \\
\text { technique was used to test the validity of the data using } \\
\text { source triangulation, which was not only taken from one } \\
\text { source but there were several sources of information that } \\
\text { supported this research including, the head of MDA, teachers, } \\
\text { and students of Tarbiyah Islamiyah } 3 \text { Nagari Kayutanam. } \\
\text { The results showed that: the application of the iqra' method } \\
\text { in learning to read the Qur'an was carried out by The } \\
\text { teacher explained, read the single hijaiyyah letters, } \\
\text { continued, long and short in front of the class using the } \\
\text { blackboard, then the students followed together, then the } \\
\text { students read one by one in front of the class using the iqra' } \\
\text { book. inhibiting factors for learning to read the Qur'an, } \\
\text { namely students who rarely enter class will miss the learning } \\
\text { process and even forget the hijaiyyah letters that have been } \\
\text { studied previously, supporting factors for the learning } \\
\text { process, namely teachers who are always patient and } \\
\text { istiqamah in teaching students until students really able to } \\
\text { read the Qur'an properly and correctly. The findings in this } \\
\text { study have proven that the application of learning to read } \\
\text { the Qur'an using the iqra' method at MDA Tarbiyah } \\
\text { Islamiyah } 3 \text { Nagari Kayutanam is in accordance with the } \\
\text { existing iqra' method theory and coupled with the creativity } \\
\text { of the teacher. }\end{array}$} \\
\hline Article history: & \\
\hline Received, 31 Januari 2022 & \\
\hline Revised, 17 Februari 2022 & \\
\hline $\begin{array}{l}\text { Accepted, } 28 \text { Februari } \\
2022\end{array}$ & \\
\hline Keywords: & \\
\hline & \\
\hline Membaca Al-Qur'an & \\
\hline Conflict of Interest: & \\
\hline None & \\
\hline & \\
\hline None & \\
\hline
\end{tabular}

Corresponding Author: Nur Hasnah, Department Islamic Education Faculty of Social Science Universitas Negeri Padang, Indonesia, Email: nhasnah566@gmail.com, Phone No: $+6283803007303$ 


\section{Pendahuluan}

Perbedaan dan persamaan penelitian peneliti dengan penelitian sebelumnya yaitu penelitian Lindah Kurniatin yang berjudul Pembelajaran Membaca Al-Qur'an Dengan Metode AnNahdliyah Pada Santri Usia Lanjut (Studi Kasus Di Dukuh Pakel Desa Pohijo Kecamatan Sampung Kabupaten Ponorogo) Tahun 2019, persamaannya yaitu sama-sama meneliti metode pembelajaran Al-Qur'an dan perbedaannya penelitian yang penelti lakukan menggunakan metode Iqra' bukan menggunakan metode annahdliyah

Belajar membaca Al-Qur'an ialah wajib hukumnya, dalam hal membaca Al-Qur'an, Said Agil Husain Al-Munawar menjelaskan bahwa Al-Qur'an merupakan firman Allah swt yang diturunkan kepada nabi Muhammad Saw, yang memiliki kemukjizatan lafal, membacanya bernilai ibadah, diriwayatkan secara mutawwatir, yang tertulis dalam mushaf, dimulai dengan surat Al-Fatihah dan diakhiri dengan surat An-Nas ( Al-Munawar, 2002). Salah satu metode yang digunakan dalam membaca Al-Quran adalah metode iqra'. Metode iqra' adalah metode membaca Al-Qur'an dengan cepat melalui pendekatan CBSA, privat dan asistensi. CBSA (Cara Belajar Siswa Aktif) artinya murid aktif sedangkan guru hanya menyimak bacaan murid kecuali hanya sekedar memberikan contoh pokok pelajaran saja. Privat, artinya guru menyimak seseorang demi seseorang, sedang bila secara klasikal dilengkapi dengan alat peraga. Asistensi, artinya setiap murid yang lebih tinggi tingkatan pelajarannya membantu menyimak murid lain yang bacaannya lebih dibawah (Yolanda, 2018).

Adapun buku panduan iqra terdiri dari 6 Jilid dimulai dari tingkat yang sederhana, tahap demi tahap sampai pada tingkatan yang sempurna. Metode iqra ini dalam prakteknya tidak membutuhkan alat yang bermacam-macam, karena ditekankan pada bacaannya (membaca huruf Al-Qur'an dengan fasih). Bacaan langsung tanpa dieja. Artinya diperkenalkan nama-nama huruf hijaiyah dengan cara belajar siswa aktif (CBSA) dan lebih bersifat individual. Metode pembelajaran ini pertama kali disusun oleh H. As'ad Humam di Yogyakarta. Buku metode iqra ini disusun/dicetak dalam enam jilid sekali. Di mana dalam setiap jilidnya terdapat petunjuk mengajar dengan tujuan untuk meudahkan murid yang akan menggunakannya, maupun guru yang akan menerapkan metode tersebut kepada muridnya (Srijatun, 2017).

MDA Tarbiyah Islamiyah 3 Nagari Kayutanam adalah pendidikan tingkat dasar yang berorientasi kepada pendidikan Agama Islam yang memfokuskan pada pembelajaran Al-Qur'an. MDA Tarbiyah Islamiyah 3 Nagari Kayutanam tidak hanya mengajarkan seni membaca Al-Quran saja tetapi juga mengajarkan tentang cara sholat yang benar, berpidato, menghafal Al-Quran dan lain sebagainya. Hasil wawancara yang dilakukan peneliti pada saat observasi pendahuluan di MDA Tarbiyah Islamiyah 3 Nagari Kayutanam pada tanggal 9 Januari 2021 dengan salah satu guru yang mengajar di MDA Tarbiyah Islamiyah 3 Nagari Kayutanam yaitu Rini Andria Roza, peneliti mendapatkan beberapa informasi atau data yang peneliti butuhkan mengenai MDA Tarbiyah Islamiyah 3 Nagari Kayutanam, diantara datadata tersebut adalah ada dari beberapa murid MDA Tarbiyah Islamiyah 3 Nagari mendapatkan juara lomba Musabaqoh Tilawatil Qur'an tingkat Provinsi dan lomba kaligrafi tingkat Kabupaten. Banyak dari alumni MDA Tarbiyah Islamiyah Kayutanam yang menjadi hafidz/hafidzah dan ada dari beberapa alumni yang di terima di MTS ternama, pesantren ternama, Universitas ternama. 
Nur Hasnah dan Indah Muliati: Penerapan Metode Iqra' dalam Pembelajaran ...

\section{Tinjauan Pustaka}

Metode iqra' adalah salah satu metode yang digunakan dalam membaca Al-Quran. Metode iqra' adalah metode membaca Al-Qur'an dengan cepat melalui pendekatan CBSA, privat dan asistensi. CBSA ( Cara Belajar Siswa Aktif) artinya murid aktif sedangkan guru hanya menyimak bacaan murid kecuali hanya sekedar memberikan contoh pokok pelajaran saja. Privat, artinya guru menyimak seseorang demi seseorang, sedang bila secara klasikal dilengkapi dengan alat peraga. Asistensi, artinya setiap murid yang lebih tinggi tingkatan pelajarannya membantu menyimak murid lain yang bacaannya lebih dibawah ( Yolanda, 2018).

Pembelajaran membaca Al-Qur'an terdiri dari: a. makharijul Huruf. Makharijul huruf adalah tempat keluarnya huruf hijaiyyah yang padanya berhenti suara dari sebuah lafadz (pengucapan) yang dengannya dibedakan suatu huruf dengan lainnya (kurnaedi, 2018 ). Pembagian Makharijul huruf di antaranya, yaitu : 1) Rongga tenggorokan dan rongga mulut (Al-Jauf), tidak tersentuh sama pihak manapun dari sisi tenggorakan, lidah, bibir tapi dia melewati rongga tenggorokan dan rongga mulut. Huruf jauf disebut dengan huruf mad. a) Alif Maddiyah: Alif yang tidak berbaris dan huruf sebelumnya berbaris fathah. Contoh : جَا : tenggorokan, rongga mulut. b) Wau Maddiyah : Wau sukun dan huruf sebelum berbaris dhommah. Contoh : سُوْ مؤ لَّو : Bibir monyong kedepan karna ada dhommah, keluar suara dari pita suara, melewati rongga tenggorokan setelah itu melewati rongga mulut dan keluar dari dua bibir. c) Ya Maddiyah : Ya sukun dan huruf sebelumnya berbaris kasroh. Contoh : بِ : بي : Keluar suara dari pita suara, melewati mulut dan keluar dari dua bibir. Cara pengucapan huruf Al-Jauf, tidak boleh ditahan nafas yang menyebab kan keluar huruf hamzah. 2). Tenggorokan (Al-Halq), a) Pangkal atau pita suara : : : : - pada lafadz, di senyumkan dua bibir penyebutan ketika 2 pita terbuka sedang. 3).

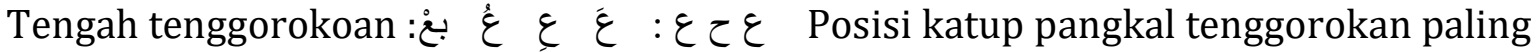
dekat ke dinding tenggorokan. بح $ح$ ح $ح$ : $ح$ : Posisi katup pangkal tenggorokan tidak terlalu dekat ke dinding tenggorokan. 4) Atas Tenggorokan : $\dot{\tau} \dot{\varepsilon}$, Pangkal lidah menyentuh rahang atas bagian daging. ب غ $\quad \dot{\varepsilon} \quad \dot{\varepsilon}: \dot{\varepsilon}$ Jaraknya sedikit, agak kebawah dekat pangkal lidah, ق : , ق : : menyentuh rahang atas bagian daging. 5) Lidah (Al-Lisan), a) Pangkal lidah Pangkal lidah yang paling jauh dari bibir, menempel pada rahang atas

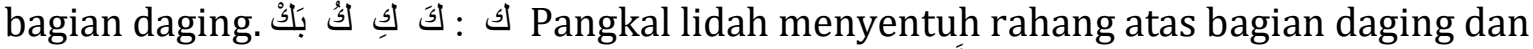
tulang secara bersamaan. b) Tengah Lidah: Pertengahan

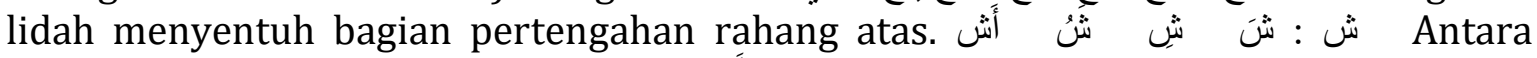
pertengahan lidah dengan rahang atas. Antara pertengahan lidah dengan pertengahan rahang atas. c) Tepi Lidah: ض ض ضَ ضَ ضُ أَضْ ,ض yang jauh dari bibir, ditempel pada gusi tempat gigi gerahang atas, boleh gigi gerahang atas bagian kiri saja atau bagian kanan saja dan keduanya juga boleh. $\mathcal{J}$ : j

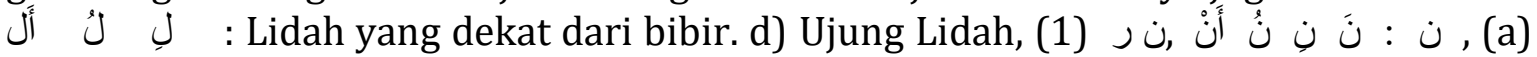
Ujung lidah bertemu dengan gusi dekat tumbuh gigi seri atas. (b) Khoisyum (Rongga

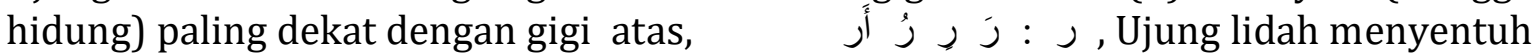
gusi atas dekat dengan makhraj huruf nun, memiliki sifat bergetar tapi tidak berlebihan dan juga tidak boleh hilang getaran (2) (2) Thorof Lidah menyentuh tempat tumbuh gigi atas, perbedaannya makhraj pangkal lidah agak dekat dengan rahang atas. أتَّ ص , Ujung lidah menyentuh dinding gigi seri bawah, suara keluar dari atas melewati 
gigi seri atas dan bawah perbedaan makhraj huruf pangkal lidah mendekati rahang

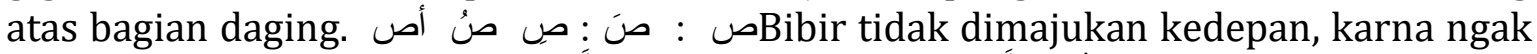

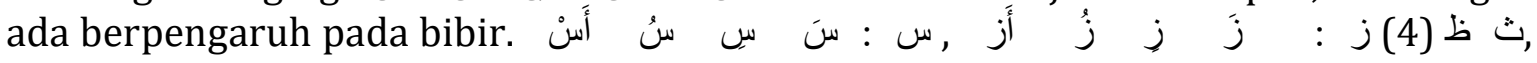
Thorof lidah menyentuh ujung gigi seri atas, perbedaan huruf pangkal lidah

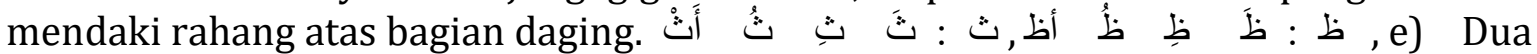

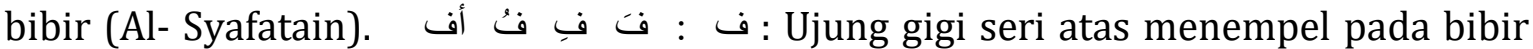
bawah yang basah, و و : و و و makhrajnya dua bibir monyong kedepan dan terangkatnya pangkal lidah. Dua Bibir (dengan cara merapatkan keduanya), Huruf mim memiliki 2 makhraj (1) Dua bibir merapat (2) Rongga hidung. f) Rongga Hidung (Al-Qaisyuum), Huruf $\dot{ }$, Thorof lidah menyentuh gusi, Rongga Hidung, Huruf $\curvearrowright$, Dua bibir merapat, Rongga Hidung. Suara gunnah (dengung). b. Hukum mad, Memanjangkan suara dengan salah satu dari huruf mad dan lin atau salah satu lin saja. Huruf mad ada 3 yaitu : alif, ya, dan wau.

Syarat-syarat mad ada 3, yaitu : Fathah sebelum alif, Kasrah sebelum ya sukun, Dhammah sebelum wau sukun. Jenis mad terbagi dua bagian, yaitu: Mad ashliy, Mad far'i. 1) Mad asliy, Mad asliy adalah yang tidak terjadi diatas sebab tertentu seperti hamzah atau sukun. Pengucapan mad asliy adalah 2 harakat. Cara membaca mad asliy membaca mad asliy ada tiga macam, yaitu : a) Tetap dibaca ketika washal dan waqaf, b)Dibaca ketika waqaf, c)Dibaca ketika washal namun tidak dibaca ketika waqaf, 2) Multahaqat mad asliy-Mad iwadh, Mad iwadh adalah adalah waqaf pada tanwin dengan fathah selain pada ta muannats dengan alif, dengan panjang 2 harakat sebagai pengganti tanwin. Panjang mad iwadh adalah 2 harakat dan tidak terjadi kecuali ketika waqaf. a) Multahaqat mad asli- mad shilah Qashirah, Mad shilah Qashirah adalah Ha dhammir ghaib mufrad mudzakkar berharakat dhammah atau kasrah, yang terletak diantara dua huruf yang berharakat dan setelahnya bukan hamzah qatha. Dibaca panjang 2 harakat ketika washal atau bersambung. Adapun ketika waqaf, maka hukumnya tidak ada mad. b) Mad thabi'i harfy, Mad thabi'iy harfy adalah Mad thabi'i yang ada pada ejaan huruf dari huruf muqathata'ah yang sebagian surah-surah Al-Qur'an dIbua dengannya, yang ejaan terdiri dari 2 huruf, yang huruf keduanya adalah huruf mad, ada 5 huruf yaitu: حا يا طا هار ا. mad ini dibaca 2 harakat. 3) Mad far'i.

Mad far'i adalah memanjangkan bacaaan huruf mad lebih dari kadar panjang mad thabi'iy karena bertemu hamzah atau sukun. a) Mad far'i karena hamzah. Sebagaimana disebutkan sebelumnya, mad far'i terjadi disebabkan oleh dua hal, yaitu sebab hamzah, dan sebab sukun. Berikut penjelasan selengkapnya. Mad far'i yang disebabkan oleh hamzah ada empat, yaitu : Mad wajib muttasil, mad jaiz munfasil, mad shilah kubra, dan mad badal. b) Mad far'i karena hamzah -Mad wajib muttasil.

Mad wajib muttasil adalah adanya hamzah setelah huruf mad yang yang muttashil atau bersambung dalam satu kata. Mad wajib muttashil pada alif, mad wajib pada ya, mad wajib muttasil pada wau. Panjangnya 4 sampai 5 harakat. c)Mad far'i karena hamzah- mad jaiz munfasil.

Mad jaiz munfasil adalah adanya huruf mad pada akhir kata pertama dan hamzah qatha pada awal kat berikutnya. Mad jaiz munfashil pada alif (1), mad jaiz munfasil pada ya (ي) , mad jaiz munfasil pada wau (و). Dibaca panjang 4 sampai 5 harakat. d) Mad far'i karena hamzah- mad shilah kubra. Mad shilah kubra adalah adanya ha dhammir ghaib mufrad mudzakar berharakat dhammah aytau kasrah yang terletak 
Nur Hasnah dan Indah Muliati: Penerapan Metode Iqra' dalam Pembelajaran...

diantara dua huruf yang berharakat dan setelahnya adalah hamzah qatha. На (०) berharakat dhammah, ha (o) berharakat kasrah. Panjang bacaannya yaitu 4 sampai 5 harakat. e) Mad far'i karena hamzah- mad badal.

Mad adalah panjang, sedangkan badal adalah pengganti. Adapun menurut istilah adalah adanya huruf hamzah yang mendahului huruf mad. hamzah berharakat fathah, dhammah kasrah. Tempo bacaan mad badal 2 harakat. f) Mad far'i karena sukun Sukun ada dua jenis, yaitu sukun aridh dan sukun ashliy. Yang disebabkan sukun aridh ada dua macam yaitu : (1)Mad aridh lis sukun,(2) Mad lin Adapun yang disebabkan sukun ashliy, ada dua bagian, yaitu : (1) Mad lazim kalimi,(2) Mad lazim harfiy. Mad lazim kalimi terbagi menjadi 2 Bagian, yaitu: (1) Mad lazim kalimi musaqqal, (2) Mad lazim kalimi mukhaffaf. Mad lazim harfiy terbagi menjadi 2 bagian, yaitu : (1) Mad lazim harfiy mutsaqqal, (2) Mad lazim harfiy mukhaffaf. g) Mad far'i karena sukun aridh. Sukun aridh adalah sukun yang terbentuk karena waqaf, sedangkan aridh artinya baru ada atau datang. Ada dua mad yang disebabkan sukun aridh atau sukun tidak asli, yaitu mad aridh lis sukun dan mad lin. h) Mad far'i karena sukun aridh- mad aridh lis sukun. i) Mad aridh lis sukun adalah adanya huruf mad sebelum huruf terakhir dalam sebuah kata dan waqaf pada akhir kata tersebut dengan sukun arid karena waqaf. Setelah huruf alif ( 1 ), ya (ي), wau (و). Tempo bacaan mad aridh lis sukun boleh dengan 2 harakat, 4 harakat, atau 6 harakat ketika waqaf. J) Mad far'i karena sukun- mad lin. Mad lin adalah adanya huruf lin sebelum huruf terakhir dalam sebuah kata, dan waqaf pada akhir kata tersebut dengan sukun aridh karena waqaf. Huruf lin terjadi pada dua keadaan pertama ketika wau (و) sukun yang sebelumnya huruf berharakat fathah, dan kedua ya (ي) sukun yang sebelumnya huruf berharakat fathah. Panjang bacaan mad lin boleh 2 harakat, 4 harakat ataupun 6 harakat ketika waqaf. h) Mad far'i karena sukun ashly.

Ada satu mad yang disebabkan karena sukun asli, yaitu mad lazim. 1) Mad far'i karena sukun asliy - mad lazim. Secara umum mad lazim adalah adanya huruf mad dan setelahnya adalah huruf yang sukun dengan sukun ashliy dalam keadaan washal ataupun waqaf pada kata itu sendiri. Mad lazim kalimi terbagi lagi menjadi dua bagian, yaitu mad lazim kalimi mutsaqqal dan mad lazim harfiy mukhaffaf. 2) Mad far'i karena sukun ashly-mad lazim kalimi mutsaqal. Mad lazim kalimi mutsaqqal adalah adanya sukun asli yang bertasydid setelah huruf mad pada satu kata. Panjang bacaaannya adalah 6 harakat. 3) Mad far'i karena sukun asliy-mad lazim kalimi mukhaffaf. Mad lazim kalimi mukhaffaf adalah adanya sukun asli mukhaffaf yang diidghamkan setelah huruf mad dalam satu kata. Panjang bacaannya adalah 6 harakat. 4)Mad far'i karena sukun ashly- mad lazim harfiy. Didalam Al-Qur'an ada 29 surah yang dimulai dengan huruf-huruf mutgha'ah. Semuanya harus dibaca ن م ل ص ق • • ح :  lazim ada 7 huruf, yaitu ; س ن ق ص ص ل ك م , Panjang bacaan mad lazim harfiy ada 6 harakat. Adapun sisa dari 14 huruf yang tidak termasuk mad lazim ada 7 huruf, yaitu

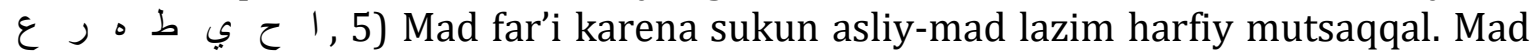
lazim harfiy mutsaqqal adalah bacaan mad pada ejaan salah satu huruf muqhata'ah yang Allah SWT memulai dengannya sebagian surah Al-Qur'an ejaannya tersusun dari tiga huruf dan pertengahan dari ketiganya adalah huruf mad sementara setelahnya huruf sukun yang di idghamkan pada huruf berikutnya. 
Tempo bacaan mad lazim harfiy mutsaqqal dibaca 6 harakat. 6) Mad far'i karena sukun asliy- Mad lazim harfiy mukhaffaf. Mad lazim harfiy mukhaffaf adalah bacaan mad pada ejaan salah satu huruf muqhatha'ah yang Allah memulai dengannya sebagian surah Al-Qur'an ejaan tersusun dari tiga huruf, dan pada pertengahan tiga huruf tersebut adalah huruf mad sementara setelahnya sukun yang tidak diidghamkan pada huruf berikutnya. Mad lazim harfi mukhaffaf ada pada huruf-huruf yang tersusun dari 3 huruf hijaiyyah dan huruf yang ketiganya tidak di idghamkan pada huruf yang lain. Tempo bacaan mad lazim harfiy mukhaffaf dibaca 6 harakat ( Kurnaedi, 2018).

\section{Metode}

Metode yang dipakai dalam penelitian ini adalah penelitian kualitatif dengan menggunakan metode analisis deskriptif (Eriyanti et al., 2020; Murniyetti et al., 2022). Penelitian yang dilakukan oleh peneliti termasuk dalam kategori studi lapangan (field research). Informan dalam penelitian ini ada 7 orang ( guru dan murid MDA Tarbiyah Islamiyah 3 Nagari Kayutanam), peneliti tetapkan menggunakan teknik purposive sampling. Pengumpulan data yang diperlukan dalam penelitian ini ialah menggunakan teknik wawancara langsung kepada seluruh informan menggunakan instrument wawancara, setiap individu informan dilaksanakan wawancara secara berulang-ulang. Untuk memperkokoh data wawancara peneliti juga melakukan observasi dengan cara terlibat langsung mengikuti kegiatan pembelajaran membaca Al-Qur'an di MDA Tarbiyah Islamiyah 3 Nagari Kayutanam. Ketepatan dan kebenaran data yang sudah berhasil digali, dikumpulkan dan dicatat dalam kegiatan penelitian harus dipastikan dengan baik. Untuk menguji kredibilitas dan pengecekan data, maka diperlukan teknik pemeriksaan. Terdapat beberapa teknik yang digunakan dalam pengecekan keabsahan temuan di antaranya yaitu perpanjangan keikutsertaan, ketekunan pengamatan, dan triangulasi.

\section{Hasil dan Pembahasan}

Temuan tema pertama penerapan metode iqra' dalam pembelajaran membaca AlQur'an di MDA Tarbiyah Islamiyah 3 Nagari Kayutanam. Pembelajaran membaca huruf hijaiyyah tunggal (Iqra' Jilid 1 ).

Wawancara pertama dengan Ibu Des pada hari senin tanggal 18 Oktober 2021, mengatakan bahwa:

"Pada saat mulainya pembelajaran, pertama-tama guru menulis huruf hijaiyyah berbaris di papan tulis dilanjutkan dengan menjelaskan satu persatu huruf hijaiyyah sesuai makhrajnya yang diiringi oleh semua murid beberapa kali pengulangan. Kemudian guru memanggil satu per satu murid maju ke meja guru untuk mengaji menggunakan buku iqra.

Wawancara kedua dengan ibu wati pada hari senin tanggal 18 oktober 2021, mengatakan bahwa:

"Dalam pembelajaran membaca Al-Qur'an ini murid di panggil satu persatu ke meja guru untuk mengaji atau belajar huruf hijaiyyah menggunakan buku iqra'. Dalam proses mengaji guru memerintahkan murid membuka buku iqra', kemudian guru menjelaskan satu persatu huruf hijaiyyah yang ada di buku iqra' dengan perlahanlahan. Pada proses menjelaskan huruf hijaiyyah, guru mengumpamakan huruf-huruf benda lain contohnya seperti huruf ta, guru memegang tangan muridnya sambil bilang 
Nur Hasnah dan Indah Muliati: Penerapan Metode Iqra' dalam Pembelajaran ...

"ini apa dek" dan muridnya bilang "tangan", nah tangan ini diawali dengan ta. Kalau lupa sebutan huruf ta ini, ingat aja tangan, ta.begitu juga dengan huruf-hurufyang lain. selanjutnya guru meminta murid untuk membacanya dengan diiringi guru, kemudian murid di minta untuk membaca sendiri sampai selesai.

Wawancara ketiga dengan murid yang bernama Nabipa Rizki Ramadhani pada hari senin tanggal 18 Oktober 2021, mengatakan bahwa:

"Pembelajarannya menyenangkan, Ibu menulis di papan tulis huruf hijaiyyah dan mejelaskan huruf hijaiyyah satu persatu dengan berirama. Setelah itu Ibu meminta kami ke meja Ibu satu persatu belajar huruf hijaiyyah menggunakan buku iqra'”

Wawancara keempat dengan murid yang bernama Muhammad Alfes pada hari senin tanggal 18 Oktober 2021, mengatakan bahwa:

"Ibu menulis huruf hijaiyyah di papan tulis, kemudian Alfes baca, kalau Alfes salah, ibu menyuruh Alfes ngulang lagi sampai bisa".

Dari hasil wawancara dengan Ibu Des dan Ibu Wati dapat diketahui bahwa, Saat memulai pembelajaran guru menulis huruf hijaiyyah tunggal di papan tulis.guru menjelaskan huruf hijaiyyah tunggal satu persatu kepada murid. Setelah guru menjelaskan kemudian guru membacakan satu persatu huruf hijaiyyah tunggal yang diikuti oleh muridnya, murid mengikuti guru dalam membaca huruf hijaiyyah tunggal beberapa kali pengulangan sampai dianggap sudah lumayan bagus, guru memanggil satu persatu murid untuk maju kedepan membaca huruf hijaiyyah tunggal yang ada di papan tulis, guru meminta murid duduk rapi kembali ditempat duduknya masingmasing, guru memanggil murid untuk ke meja guru, guru menyuruh murid membaca huruf hijaiyyah tunggal menggunakan buku iqra', Guru mengiringi murid dalam membacanya kemudian murid diminta membaca sendiri huruf hijaiyyah tunggal yang ada di dalam buku iqra'.

Dari hasil wawancara dengan murid dapat diketahui bahwa, murid menyukai cara yang digunakan guru dalam mengajarkan huruf hijaiyyah tunggal karna pertamatama guru menuliskan huruf hijaiyyah tunggal di papan tulis kemudian guru mejelaskan huruf hijaiyyah satu persatu. Setelah itu guru meminta murid untuk ke meja guru belajar huruf hijaiyyah tunggal menggunakan buku iqra.'

Hasil wawancara di atas diperkuat dengan observasi yang penulis lakukan pada tanggal 18 Oktober 2021, Guru menjelaskan pembelajaran menggunakan papan tulis, guru menulis huruf hijaiyyah dipapan tulis, dilanjutkan dengan menjelaskan huruf hijaiyyah yang ditulis dipapan tulis. Semua murid memperhatikan guru dalam menjelaskan pelajaran, Guru menjelaskan huruf hijaiyyah dengan perlahan - lahan Perlahan-lahan disini maksudnya, guru menjelaskan huruf hijaiyyah satu persatu. Contohnya guru menjelaskan huruf alif Alif (1) kemudian di lafadzkan oleh guru dan ikuti oleh murid beberapa kali sampai murid bisa, guru membaca huruf hijaiyyah dengan beirama, irama ini difungsikan ketika guru sudah menjelaskan semua huruf hijaiyyah dari Alif ( 1 ) sampai ya (ي),tujuan irama ini untuk membuat murid agar tidak bosan, Murid secara bergiliran ke depan kelas untuk membaca huruf hijaiyyah yang ada di papan tulis, Setelah guru selesai menjelaskan pembelajaran didepan kelas, tahap selanjutnya murid secara bergantian ditunjuk maju kedepan kelas mempraktekkan apa yang telah di pelajari atau diajarkan guru. Bagi murid yang tidak bisa membaca huruf hijaiyyah maka guru akan membetulkan dengan cara yang baik, guru meminta murid untuk duduk rapi kembali ke tempat duduknya masing-masing, 
Setelah murid sIbu mendengarkan guru menjelaskan pembelajaran huruf hijaiyyah menggunakan papan tulis dan bergiliran maju kedepan kelas mempraktekkan apa yang telah di ajarkan guru. Guru kemudian menertibkan kelas dengan meminta murid duduk rapi, guru meminta murid untuk ke meja guru secara bergantian belajar huruf hijaiyyah menggunakan buku iqra', Pertama-tama guru mengiringi murid membaca ta'audz dan basmalah kemudian guru menjelaskan terlebih dahulu huruf-huruf hijaiyyah yang ada di buku iqra' sesuai dengan makhrajnya. Kemudian guru meminta murid membaca sendiri, ketika murid salah dalam membaca salah satu huruf hijaiyyah maka guru memperbaiki sampai murid tersebut bisa.

Dari hasil observasi dan wawancara peneliti dengan guru dan murid mengenai kegiatan inti pembelajaran huruf hijaiyyah di MDA Tarbiyah Islamiyah 3 Nagari Kayutanam maka didapatkan hasil sebagai berikut, guru menjelaskan huruf hijaiyyah dipapan tulis, murid satu persatu maju ke meja guru dengan membawa buku iqra', murid membaca huruf hijaiyyah yang ada di iqra'.

Pembelajaran membaca huruf hijayyah bersambung ( Jilid 2). Wawancara pertama dengan Ibu Des pada hari senin tanggal 25 Oktober 2021, mengatakan bahwa:

"Pembelajaran membaca huruf hijaiyyah yang bersambung, guru menulis dan menjelaskan didepan kelas menggunakan papan tulis, guru menjelaskannya dengan cara perlahan-lahan selanjutnya guru menunjuk beberapa murid untuk maju ke depan mempraktekkan apa yang telah diajarkan guru, bagi murid yang tidak bisa atau lupa maka akan dibetulkan oleh guru. Setelah semuanya selesai, guru mengarahkan murid untuk duduk rapi kembali. Kemudian guru memanggil murid secara bergiliran ke meja guru untuk membaca huruf hijaiyyah yang bersambung menggunakan buku iqra'. Pertama guru membaca dan menjelaskan huruf hijaiyyah yang terdapat dalam buku iqra' selanjutnya guru meminta murid untuk membacanya, ketika murid salah maka guru akan membenarkannya dengan perlahan-lahan.

Wawancara kedua dengan murid yang bernama Arkhan Athalla Smery pada hari Senin tanggal 25 Oktober 2021, mengatakan bahwa:

"Pertama Ibu tu menulis huruf di papan tulis, kemudian kita membaca bersamasama, setelah itu kita hafal huruf itu, kalau kita salah di ulang sampai bisa, setelah itu kita di suruh duduk kembali ketempat masing-masing."

Wawancara ketiga dengan murid yang bernama Noor Farisya Humairah pada hari Senin tanggal 25 Oktober 2021, mengatakan bahwa:

"Ibu guru menjelaskan pembelajaran membaca huruf hijaiyyah bersambung dipapan tulis Arkhan dan teman-teman yang lain kedepan membaca huruf hijaiyyah yang bersambung yang ditunjuk di papan tulis. Kemudian Ibu guru memanggil kami satu persatu untuk ke meja Ibu membaca huruf hijaiyyah bersambung menggunakan buku iqra'". Dari hasil wawancara dengan guru dan murid dapat diketahui bahwa, saat memulai pembelajaran guru menulis huruf hijaiyyah bersambung di papan tulis, guru menjelaskan huruf hijaiyyah bersambung satu persatu kepada murid, setelah guru menjelaskan kemudian guru membacakan satu persatu huruf hijaiyyah bersambung yang diikuti oleh muridnya, murid mengikuti guru dalam membaca huruf hijaiyyah bersambung beberapa kali pengulangan sampai dianggap sudah lumayan bagus, guru memanggil satu persatu murid untuk maju kedepan membaca huruf hijaiyyah bersambung yang ada di papan tulis, guru meminta murid duduk rapi kembali ditempat duduknya masing-masing, guru memanggil murid untuk ke meja guru, guru menyuruh murid membaca huruf hijaiyyah bersambung menggunakan 
Nur Hasnah dan Indah Muliati: Penerapan Metode Iqra' dalam Pembelajaran ...

buku iqra', guru mengiringi murid dalam membacanya kemudian murid diminta membaca sendiri huruf hijaiyyah bersambung yang ada di dalam buku iqra'.

Hasil wawancara di atas diperkuat dengan observasi yang peneliti lakukan pada tanggal 25 Oktober 2021, Guru menjelaskan pembelajaran menggunakan papan tulis, pertama-tama guru menulis huruf hijaiyyah bersambung dipapan tulis, dilanjutkan dengan menjelaskan huruf hijaiyyah yang di tulis dipapan tulis. Semua murid memperhatikan guru menjelaskan pembelajaran, guru menjelaskan huruf hijaiyyah bersambung dengan perlahan-lahan,perlahan-lahan disini maksudnya, guru menjelaskan huruf hijaiyyah satu persatu. Contohnya guru menjelaskan huruf bersambung (هُوَ) kemudian di lafadzkan oleh guru dan ikuti oleh murid beberapa kali sampai murid bisa, guru menyebutkan huruf hijaiyyah yang bersambung dengan berirama, irama ini difungsikan menyebut semua huruf hijaiyyah, ketika guru sudah menjelaskan semua huruf hijaiyyah bersambung, tujuan dari irama ini membuat murid agar tidak bosan, murid secara bergiliran ke depan kelas membaca huruf hijaiyyah yang ada di papan tulis, setelah guru selesai mejelaskan pembelajaran di depan kelas, tahap selanjutnya murid secara bergantian di panggil maju kedepan kelas mempraktekkan apa yang telah di pelajari atau diajarkan guru.

Bagi murid yang tidak bisa melafadzkan huruf hijaiyyah bersambung maka guru akan membetulkan dengan cara yang baik, murid duduk rapi kembali ke tempat duduknya masing-masing, setelah murid sIbu mendengarkan guru menjelaskan pembelajaran huruf hijaiyyah bersambung menggunakan papan tulis dan bergiliran maju kedepan mempraktekkan apa yang telah di ajarkan guru. Guru kemudian menertibkan kelas dengan meminta murid duduk rapi, guru memanggil satu persatu murid untuk maju ke meja guru membaca huruf hijaiyyah menggunakan buku iqra', guru meminta murid membuka buku iqra' kemudian murid membaca ta'audz dan basmalah kemudian guru menjelaskan terlebih dahulu huruf-huruf hijaiyyah yang bersambung yang ada di buku iqra' secara perlahan-lahan, kemudian guru meminta murid membaca sendiri, ketika salah satu dari murid salah dalam membaca huruf hijaiyyah yang bersambung maka guru mengulangi lagi untuk membetulkan.

Dari hasil observasi dan wawancara peneliti dengan guru dan murid mengenai kegiatan inti metode iqra' di MDA Tarbiyah Islamiyah 3 Nagari Kayutanam maka didapatkan hasil, guru menjelaskan huruf hijaiyyah bersambung dipapan tulis, guru memanggil satu-persatu murid maju ke meja guru dengan membawa buku iqra', murid membaca huruf hijaiyyah bersambung menggunakan buku iqra'.

Pembelajaran membaca huruf hijaiyyah panjang (mad) dan pendek (Iqra' jilid 2), wawancara pertama dengan Ibu Des pada hari senin tanggal 1 November 2021, mengatakan bahwa:

"Kegiatan inti pembelajaran membaca huruf hijaiyyah panjang dan pendek, guru mengawalinya dengan menjelaskan menggunakan papan tulis. Guru membuat huruf hijaiiyah panjang dan pendek dan dilanjutkan dengan menjelaskan kepada muridmurid. Agar murid mampu membedakan mana yang panjang dan pendek maka guru menyampaikan ciri-ciri dari huruf yang panjang ada alifnya panjangnya 2 ketukan sambil dipraktekkan. Setelah guru menjelaskan satu persatu beberapa kali pengulangan selanjutnya guru meminta beberapa murid untuk ke depan kelas membaca apa yang di suruh oleh guru. Setelah selesai menjelaskan pembelajaran menggunakan papan tulis selanjutnya guru meminta murid untuk duduk tenang dan rapi. Guru memanggil satu persatu murid secara bergiliran menghadap guru untuk membaca huruf hijaiyyah panjang dan pendek menggunakan buku iqra'. Seperti biasa 
guru meminta murid untuk membuka buku iqra' dan terlebih dahulu guru membaca sambil mejelaskan kemudian guru meminta kepada murid untuk membacanya sendiri. Ketika murid tersebut salah dalam membacanya maka guru membantu".

Wawancara kedua dengan murid yang bernama Mirza Said Marna pada hari senin tanggal 1 November 2021, mengatakan bahwa:

"Guru menulis dipapan tulis dan menjelaskannya dengan cara menyampaikan kalau yang panjang ada alifnya di umpamakan ada tangkainya dan untuk mengukur panjang dari huruf guru mengajarkan cara mengukurnya dengan ketukan. Sehingga membuat mudah diingat karna menarik".

Wawancara ketiga dengan murid yang bernama Mutia Yunita pada hari senin tanggal 1 November 2021 mengatakan bahwa:

"Ibu guru menjelaskan pelajaran mengguakan papan tulis di papan tulis, Kemudian Ibu memanggil kami satu persatu untuk ke meja Ibu membaca huruf hijaiyyah panjang dan pendek menggunakan buku iqra'. Jika mutia tidak bisa membaca salah satu huruf hijaiyyah panjang dan pendek maka Ibu menjelaskan lagi kepada mutia agar mutia mengingat apa yang telah di pelajari".

Dari hasil wawancara dengan guru dan murid dapat diketahui bahwa saat memulai pembelajaran guru menulis huruf hijaiyyah panjang (mad) dan pendek di papan tulis, guru menjelaskan huruf hijaiyyah panjang (mad) dan pendek satu persatu.setelah guru menjelaskan kemudian guru membacakan satu persatu huruf hijaiyyah panjang (mad) dan pendek yang diikuti oleh muridnya, murid mengikuti guru dalam membaca huruf hijaiyyah panjang (mad) dan pendek beberapa kali pengulangan sampai dianggap sudah lumayan bagus, guru memanggil satu persatu murid untuk maju kedepan membaca huruf hijaiyyah panjang (mad) dan pendek yang ada di papan tulis, guru meminta murid duduk rapi kembali ditempat duduknya masingmasing, guru memanggil murid satu persatu untuk ke meja guru, guru menyuruh murid membaca huruf hijaiyyah panjang (mad) dan pendek menggunakan buku iqra', guru mengiringi murid dalam membaca huruf hijaiyyah panjang (mad) dan pendek kemudian murid diminta membaca sendiri huruf hijaiyyah panjang (mad) dan pendek yang ada di dalam buku iqra',

Hasil wawancara di atas diperkuat dengan observasi yang peneliti lakukan pada tanggal 1 November 2021, guru menjelaskan pembelajaran menggunakan papan tulis, guru menulis huruf hijaiyyah panjang dan pendek di papan tulis. Di lanjutkan dengan menjelaskannya kepada murid-murid dengan menyampaikan ciriciri dari huruf yang panjang, dengan penjelasan guru tersebut banyak murid yang antusias untuk mempraktekkan di buku tulis masing-masing tanpa di minta oleh guru, murid secara bergantian ke depan kelas membaca huruf hijaiyyah panjang dan pendek yang telah diajarkan guru, setelah guru selesai menjelaskan pembelajaran didepan kelas, tahap selanjutnya secara bergantian murid di minta kedepan kelas mempraktekkan apa yang telah di pelajari atau diajarkan guru.

Bagi murid yang tidak bisa melafadzkan huruf hijaiyyah panjang dan pendek maka guru akan membetulkan dengan cara yang baik, murid duduk rapi kembali di tempat duduknya masing-masing, setelah murid sibuk mendengarkan guru menjelaskan pembelajaran huruf hijaiyyah panjang dan pendek menggunakan papan tulis dan bergiliran maju kedepan mempraktekkan apa yang telah diajarkan guru, guru kemudian menertibkan kelas dengan meminta murid duduk rapi di tempat masingmasing, para murid secara bergiliran belajar huruf hijaiyyah panjang dan pendek menggunakan buku iqra' di meja guru, pertama-tama guru memanggil nama setiap 
Nur Hasnah dan Indah Muliati: Penerapan Metode Iqra' dalam Pembelajaran ...

murid secara bergantian, bagi murid yang namanya terpanggil diminta untuk langsung kemeja guru dengan membawa buku iqra', murid kemudian membuka buku iqra', membaca ta'audz dan basmalah. Selanjutnya guru menjelaskan terlebih dahulu huruf-huruf hijaiyyah panjang dan pendek yang ada di buku iqra' secara perlahanlahan, Kemudian guru meminta murid membaca sendiri. Ketika murid salah dalam membaca salah satu huruf hijaiyyah yang panjang dan pendek maka guru mengulangi lagi untuk membacanya sehingga dapat diingat oleh murid.

Dari hasil observasi dan wawancara peneliti dengan guru dan murid mengenai kegiatan inti pembelajaran di MDA Tarbiyah Islamiyah 3 Nagari Kayutanam maka didapatkan hasil, guru menjelaskan huruf hijaiyyah panjang dan pendek menggunakan papan tulis, guru memilih beberapa murid secara bergiliran kedepan membaca huruf hijaiyyah panjang dan pendek, murid maju ke meja guru dengan membawa buku iqra',

Temuan tema kedua, Faktor Penghambat dan Pendukung Penerapan Metode Iqra' Dalam Pembelajaran Membacaaca Al-Qur'an Di MDA Tarbiyah Islamiyah 3 Nagari Kayutanam. wawancara pertama dengan ibu Des pada hari Senin tanggal 1 November 2021, mengatakan bahwa:

"Faktor penghambat pada metode iqra' terletak pada cara mengajar yang klasikal. Dengan cara klasikal ini tidak semua murid yang bisa paham, karena pada metode iqra' ini lebih fokus kepada privat. Sedangkan faktor pendukung metode iqra' yaitu bahan ajarnya (buku iqra') mudah ditemukan dan dari segi fasilitas di MDA ini sudah memadai.

Wawancara kedua dengan Kepala MDA Tarbiyah Islamiyah 3 Nagari Kayutanam yang bernama Ibu Rahilah pada hari Senin tanggal 1 November 2021, mengatakan bahwa:

"Di MDA ini masih menggunakan metode iqra'. Metode iqra' masih berlanjut sampai sekarang karena kita sadar akan dengan kapasitas guru. Faktor penghambat dari metode iqra' ini hanya terletak pada penempatannya yang klasikal. Adapun faktor penghambatnya dari metode ini yaitu rata-rata semua guru disini paham dengan metode iqra' dan buku iqra' ini mudah dicari di toko-toko buku. Mengenai fasilitas untuk metode iqra' ini InsyaaAllah sudah memadai, dan apabila guru kekurang fasilitas maka kami bersedia untuk memenuhinya.

Dari hasil wawancara dengan guru dan kepala sekolah diatas dapat diketahui bahwa, faktor penghambat metode iqra' dapat dilihat dari jumlah murid yang lumayan banyak dalam satu kelas, adanya murid yang jarang masuk kelas, faktor pendukung metode iqra' dapat dilihat dari adanya guru yang selalu istiqamah dan sabar dalam mendidik para murid, tersedianya sarana dan prasarana memadai (buku iqra', Al-Qur'an dan media pembelajaran) yang mendukung kegiatan belajar membaca Al-Qur'an, Adanya dorongan orang tua untuk mengantarkan anaknya mengaji dan juga semnagat mengajari anaknya di rumah.

Hasil dari wawancara dikuatkan dengan observasi di MDA Tarbiyah Islamiyah 3 Nagari Kayutanam pada tanggal 15 Oktober sampai 1 November 2021, peneliti menemukan bahwa faktor penghambat metode iqra' dapat dilihat dari jumlah murid yang lumayan banyak dalam satu kelas, adanya murid yang jarang masuk kelas. Sedangkan faktor pendukung pada metode iqra' ini, adanya guru yang selalu istiqamah dan sabar dalam mendidik para murid, tersedianya sarana dan prasarana yang memadai mulai dari buku iqra', Al-Qur'an dan media pembelajaran yang mendukung kegiatan belajar membaca Al-Qur'an, adanya dorongan orang tua 
untuk mengantarkan anaknya mengaji dan juga semnagat mengajari anaknya di rumah. Jadi dapat disimpulkan bahwa faktor penghambat dari metode iqra' di MDA Tarbiyah Islamiyah 3 Nagari Kayutanam, bagi murid yang jarang masuk kelas, keterbatasan waktu belajar. Sedangkan faktor pendukung dari metode iqra' di MDA Tarbiyah Islamiyah 3 Nagari Kayutanam, fasilitas yang memadai, buku iqra' yang mudah ditemukan, guru yang sabar dan istiqamah, dorongan orang tua murid.

Pembelajaran pada umumnya merupakan pemberian informasi baru kepada murid untuk mengetahui manfaat atau kegunaan dari pembelajaran tersebut. Guru memberikan informasi kepada muridnya dengan menggunakan metode yang berbeda-beda supaya proses belajar mengajar dapat terlaksana secara efektif dan mencapai tujuan yang ingin dicapai. Metode dalam pembelajaran Al-Quran: 1. Metode Baghdadi karya Abu Mansyur Hafzul Fikkir dari Baghdad. 2. Metode Qira'ati yang disusun oleh H. Dahlan Salim Zarkasyi. 3. Metode An-Nahdliyah yang disusun oleh sebuah lembaga pendidikan Ma'arif cabang Tulungagung. 4. Metode Jibril karya K.H. M. Bashori. 5. Metode Yanbu'a karya K. H. Muhammad Ulin Nuha Arwani. 6. Metode Iqra' karya As'ad Humam dari Yogyakarta.

Metode pembelajaran Al-Qur'an yang digunakan di MDA Tarbiyah Islamiyah 3 Nagari Kayutanam ialah metode iqra'. Tahapan-tahapan penerapan metode iqra'dalam pembelajaran AL-Qur'an, sebagai berikut: Pertama. Iqra' Jilid 1, Pelajaran pada jilid 1 ini seluruhnya berisi pengenalan bunyi huruf-huruf tunggal berharokat fathah. Di awali dengan huruf $A-B a, B a-T a, B a-T a-T s a$ dan seterusnya sampai bunyi huruf ya dan kemudian diakhiri dengan halaman EBTA. Jika diperhatikan isi materi pada jilid 1 ini, maka dapat diketahui bahwa target yang ingin dicapai yaitu: Pertama, Anak bisa membaca dan mengucapkan secara fasih sesuai dengan tunggal berharokat fathah. Dalam hal ini anak belum ditargetkan untuk mengenal nama-nama huruf itu sendiri, seperti Alif, $B a^{\prime}, T a$, dan seterusnya.

Kedua, Anak bisa membedakan secara tepat bunyi huruf-huruf yang memiliki makharijul huruf berdekatan seperti antara $A$ dengan ' $A$, antara Sa dengan Sya, antara Sa dengan Tsa. Kedua. Iqra' Jilid 2, kelanjutan jilid 1. Kalau pada jilid 1 anak baru dikenalkan dengan bunyi huruf-huruf tunggal berharokat fathah, maka pada jilid 2 ini diperkenalkan dengan bunyi huruf-huruf bersambung berharokat fathah. Baik huruf sambung di awal, di tengah maupun di akhir kata. Pada halaman 16 jilid 2, mulai diperkenalkan bacaan mad (panjang) namun masih tetap berharokat fathah. Mulai pada halaman ini, anak mulai boleh diperkenalkan nama huruf alif sebagai tanda bahwa bacaan huruf yang diikutinya dibaca panjang, yang terpenting harus jelas beda mana bacaan yang panjang dan mana bacaan yang pendek. Demikian juga nama tanda baca fathah, juga sudah boleh diperkenalkan kepada anak, baik fathah yang dibaca pendek maupun fathah yang dibaca panjang (fathah berdiri). Target yang ingin dicapai oleh jilid 2 ini yaitu: Pertama, Meningkatkan kefasihan membaca bunyi huruf. Kedua, Anak bisa membaca huruf-huruf sambung. Ketiga, Anak bisa membedakan bacaan pendek dan panjang dari fathah yang diikuti alif dan fathah berdiri (KH. As'ad Humam, 2000)

Penerapan pembelajaran baca tulis Al-Qur'an menggunakan metode iqra' di MDA Tarbiyah Islamiyah 3 Nagari Kayutanam, sesuai dengan teori metode iqra' yang ada dan ditambah dengan kreativitas dari guru tersebut. Hal tersebut dapat peneliti simpulkan dengan cara observasi dan wawancara dengan beberapa pihak yang bersangkutan. 
Nur Hasnah dan Indah Muliati: Penerapan Metode Iqra' dalam Pembelajaran ...

Penerapan metode iqra' dalam pembelajaran Membaca Al-Qur'an di MDA Tarbiyah Islamiyah 3 Nagari Kayutanam dilakukan dengan beberapa tahapan Pertama, Diawal pembelajaran, setiap harinya guru mengenalkan terlebih dahulu huruf asli dari huruf hijaiyyah menggunakan papan tulis. Kedua, Guru menjelaskan satu persatu huruf hijaiyyah sesuai makhrajnya dengan perlahan-lahan dan berirama. Ketiga, Murid kembali di suruh duduk, tahap selanjutnya guru memanggil nama murid satu per satu maju ke meja guru untuk membaca huruf hijaiyyah menggunakan buku iqra'. Dalam menjelaskan huruf hijaiyyah yang ada dIbuu iqra', guru mengumpamakan hurufhuruf menggunakan benda lain contohnya seperti huruf Ta dalam buku iqra', guru memegang tangan muridnya sambil bilang "ini apa dek" dan muridnya bilang "tangan", nah tangan ini diawali dengan Ta. Kalau lupa sebutan huruf ta ini, ingat tangan, begitu juga dengan huruf-huruf yang lain. Selanjutnya guru meminta murid untuk membaca huruf hijaiyyah dengan diiringi guru, kemudian murid di minta untuk membaca sendiri sampai selesai.

Penerapan metode iqra' dalam pembelajaran menulis Al-Qur'an di MDA Tarbiyah Islamiyah 3 Nagari Kayutanam, dilakukan dengan beberapa tahap : Pertama, Diawal pembelajaran, setiap harinya guru mengenalkan terlebih dahulu huruf asli dari huruf hijaiyyah menggunakan papan tulis. Kedua, guru menjelaskan huruf hijaiyyah tunggal mulai dari Alif ( I ) sampai (ي), huruf hijaiyyah bersambung, huruf hijaiyyah panjang (mad) dan pendek). Guru juga mengenalkan bahwa, menulis huruf hijaiyah dimulai dari sebelah kanan ke sebelah kiri, guru menjelaskan cara menulis alif dari atas kebawah begitu juga cara menulis huruf lainnya. Ketiga, murid menulis atau menyalin huruf hijaiyyah yang ada dIbuu iqra' ke buku tulis, kemudian hasil tulisan murid di berikan ke pada guru untuk dinilai.

Faktor Pengambat dan Pendorong penerapan metode Iqra' dalam Pembelajaran Membaca Al-Qur'an di MDA Tarbiyah Islamiyah 3 Nagari Kayutanam, Faktor penghambat dari metode iqra' di MDA Tarbiyah Islamiyah 3 Nagari Kayutanam yaitu :(1) Murid, Bagi murid yang jarang masuk kelas akan ketinggalan pelajaran dan bahkan lupa dengan huruf-huruf hijaiyah. Untuk mengatasinya maka guru di MDA Tarbiyah Islamiyah 3 Nagari Kayutanam tegas untuk tidak menaikkan jilid bahkan menurunkan jilid, jika masih terbata-bata dalam membaca iqra'. (2) Waktu belajar, Penggunaan waktu 2 jam untuk 51 murid sepertinya tidak mencukupi waktu belajar. Maka untuk mengatasinya, guru memberikan tugas kepada murid untuk menambah pelajaran di rumah.

Faktor pendukung dari metode iqra' di MDA Tarbiyah Islamiyah 3 Nagari Kayutanam yaitu :(1) Fasilitas yang memadai, fasilitas di MDA Tarbiyah Islamiyah 3 Nagari Kayutanam sudah memadai, mulai dari buku iqra', Al-Qur'an, papan tulis, dll. Jika ada kekurangan fasilitas, maka Kepala MDA pun bersedia untuk memenuhinya. (2) Buku iqra' yang mudah ditemukan, buku iqra' ini mudah ditemukan di toko-toko buku dan harganya juga terjangkau, serta buku juga disediakan di MDA Tarbiyah Islamiyah 3 Nagari Kayutanam untuk memudahkan murid membeli buku. (3) Guru, guru yang selalu sabar dan istiqamah dalam mengajarkan murid hingga murid benar-benar mampu membaca Al-Qur'an dengan baik dan benar. (4) Dorongan Orang tua murid, dorongan orang tua murid juga sangat membantu dalam proses pembelajaran Al-Qur'an pada metode iqra' ini. Terutama bagi orang tua yang selalu memperhatikan cara mengaji anaknya baik itu di MDA maupun di rumah. 


\section{Simpulan}

Berdasarkan hasil penelitian tentang penerapan metode iqra' dalam pembelajaran membaca Al-Qur'an di MDA Tarbiyah Islamiyah 3 Nagari Kayutanam dapat ditarik kesimpulan sebagai berikut: a. Kegiatan inti, 1) Pembelajaran membaca huruf hijaiyyah tunggal, tahap-tahapnya adalah guru menjelaskan, membacakan huruf hijaiyyah tunggal didepan kelas menggunakan papan tulis, kemudian murid mengikuti bersama, setelahnya murid membaca satu persatu kedepan kelas menggunakan buku iqra'. 2) Pembelajaran membaca huruf hijaiyyah bersambung, tahap-tahapnya adalah guru menjelaskan, membacakan huruf hijaiyyah tunggal didepan kelas menggunakan papan tulis, kemudian murid mengikuti bersama, setelahnya murid membaca satu persatu kedepan kelas menggunakan buku iqra'. 3) Pembelajaran membaca huruf hijaiyyah panjang (mad) dan pendek, tahap-tahapnya adalah guru menjelaskan, membacakan huruf hijaiyyah tunggal didepan kelas menggunakan papan tulis, kemudian murid mengikuti bersama, setelahnya murid membaca satu persatu kedepan kelas menggunakan buku iqra'.

\section{Referensi}

Kurniatin, L. (2019). pembelajaran membaca al-qur'an dengan metode annahdliyah pada santri usia lanjut (studi kasus di dukuh pakel desa pohijo kecamatan sampung kabupaten ponorogo) tahun 2019 (Doctoral dissertation, IAIN Ponorogo).

Al-Munawar, S. A. H. (2002). Al-Qur'an Membangun Tradisi Kesalehan Hakiki, Jakarta: Ciputat Press.

Yolanda, D. N. (2018). Peningkatan Kemampuan Baca Al-Qur; an melalui Penggunaan Gadget pada Peserta Didik di MAN 3 Aceh Besar (Doctoral dissertation, UIN Ar-Raniry Banda Aceh).

Srijatun, S. (2017). Implementasi Pembelajaran Baca Tulis al-Qur'an dengan Metode Iqra pada Anak Usia Dini di RA Perwanida Slawi Kabupaten Tegal. Nadwa: Jurnal Pendidikan Islam, 11(1).

Kurnaedi, A. Y. L. (2018). Tajwid Lengkap Asy-Syafi'i. Jakarta: Pustaka Imam Asy Syafi'i.

Wawancara dengan Ibu Des 18 Oktober 2021, 25 Oktober 2021, 1 November 2021

Wawancara dengan Ibu wati 18 Oktober 2021

Wawancara dengan Nabipa Rizki Ramadhani 18 Oktober 2021

Wawancara dengan Muhammad Alfes 18 Oktober 2021

Wawancara dengan Arkhan Athalla Smery 25 Oktober 2021

Wawancara dengan Noor Farisya Humairah 25 Oktober 2021

Wawancara dengan Mirza Said Marna 1 November 2021

Wawancara dengan Mutia Yunita 1 November 2021 